\title{
Voluntary recycling despite disincentives
}

\section{Appendix}

Similarly to other studies in environmental economics (Brekke, Kverndokk, and Nyborg 2003; Hage, Soderholm, and Berglund 2009; Nyborg, Howarth, and Brekke, 2006), the estimation model is underpinned by a constrained utility-maximisation framework, within which the process of giving to a public good is considered to generate utility (Andreoni 1990). More specifically, the model assumes that while the process of separating waste yields satisfaction, it also requires households to dedicate scarce resources, and that households choose the combination of goods and activities in a manner that maximises their well-being within their constraints.

We start by considering a household's utility (U) to be a (well-behaved) function of some composite $(\mathrm{x})$ of all goods and services that its members can buy (excluding waste services) and of (e) some composite of non-market goods and services, including environmental quality, that they perceive to enjoy. Household members also get utility from expected social respect (s) as well as from conforming to their own morality (a). In this model, elements that contribute to a household's utility also include (clear) leisure time $\left(1^{c}\right)$, defined as total leisure time $\left(1^{t}\right)$ less the time spent recycling $\left(1^{r}\right)$ and the use of (clear) household space $\left(v^{c}\right)$, defined as the area of physical space available for all household activities after storage of recycling waste $\left(v^{r}\right)$. This function is conditional on household characteristics (d).

If $\mathrm{i}$ is an index that represents a household, then the Utility of household $\mathrm{i}$ can be written as follows:

$$
\text { (1) } U_{i}=U_{i}\left(x_{i}, e_{i}, a_{i}, s_{i}, v_{i}^{c}, 1_{i}^{c} ; d_{i}\right)
$$

In line with the notion of warm-glow giving (Andreoni 1990), we consider the possibility that recycling effort, defined as kilograms of separated waste $\left(\mathrm{w}^{\mathrm{r}}\right)$, contributes to a household's total moral well-being (a). We stipulate that this relationship can be positively influenced by government communication $\left(\mathrm{GC}^{\mathrm{r}}\right)$, which can, for instance, increase the sense of responsibility ascription, consequence awareness and efficacy belief.

(2) $\mathrm{a}_{\mathrm{i}}=\mathrm{a}_{\mathrm{i}}\left(\mathrm{w}_{\mathrm{i}}^{\mathrm{r}} ; \mathrm{GC}^{\mathrm{r}}\right)$ where $\delta \mathrm{a}_{\mathrm{i}} / \delta \mathrm{w}_{\mathrm{i}}^{\mathrm{r}}>0$ and $\left(\delta \mathrm{a}_{\mathrm{i}} / \delta \mathrm{w}_{\mathrm{i}}^{\mathrm{r}}\right) / \delta \mathrm{GC}^{\mathrm{r}}>0$

We further consider that perceived social-respect (s) decreases the further away is the household's recycling from the perceived norm $\left(\mathrm{w}^{\mathrm{rn}}\right)$, and, for simplicity that at the initial stages of the scheme $\mathrm{w}_{\mathrm{i}}^{\mathrm{r}}<\mathrm{w}^{\mathrm{rn}}$. Government communication efforts $\left(\mathrm{GC}^{\mathrm{r}}\right)$ can influence what a household perceives to be the norm, as can the frequency of kerbside collection $\left(\mathrm{GF}^{\mathrm{r}}\right)$, which increases the extent of visibility of recycling by others and which may therefore serve as normative communication. This assumes, not unreasonably, that the presence of recyclables at the kerb sends a stronger signal than their absence.

(3) $\mathrm{s}_{\mathrm{i}}=\mathrm{s}_{\mathrm{i}}\left(\left|\mathrm{w}_{\mathrm{i}}^{\mathrm{r}}-\mathrm{w}^{\mathrm{rn}}\right|\left(\mathrm{GC}^{\mathrm{r}}, \mathrm{GF}^{\mathrm{r}}\right)\right)$ where $\delta \mathrm{s}_{\mathrm{i}} / \delta \mathrm{w}_{\mathrm{i}}^{\mathrm{r}}>0, \delta \mathrm{w}^{\mathrm{rn}} / \delta \mathrm{GC}^{\mathrm{r}}>0$, and $\delta \mathrm{w}^{\mathrm{rn}} / \delta \mathrm{GF}^{\mathrm{r}}>0$

The environmental quality that the household perceives to enjoy (e) increases with the household's own recycling $\left(\mathrm{w}^{\mathrm{r}}\right)$, and with the perceived recycling effort by all other households $\left(\mathrm{w}^{\mathrm{rn}}\right)$. While (a) and (s) capture "private good" type benefits, (e) captures the 
expected utility to be gained from an improved public good, including the satisfaction of purely altruistic preferences.

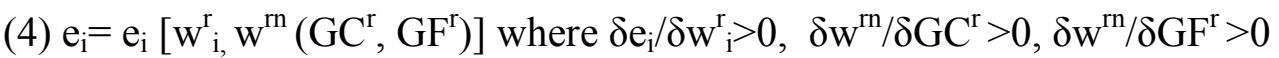

Substituting, gives:

(5) $\mathrm{U}_{\mathrm{i}}=\mathrm{U}_{\mathrm{i}}\left(\mathrm{x}_{\mathrm{i}}, \mathrm{l}_{\mathrm{i}}^{\mathrm{c}}, \mathrm{v}_{\mathrm{i},}^{\mathrm{c}}, \mathrm{w}_{\mathrm{i}}^{\mathrm{r}}, \mathrm{w}^{\mathrm{rn}} ; \mathrm{d}_{\mathrm{i}}, \mathrm{GC}^{\mathrm{r}}, \mathrm{GF}^{\mathrm{r}}\right)$

That is, utility is a function of composite goods and services, leisure time and household space (left over after recycling). It is also a function of waste separation activity, given that this yields positive utility by increasing intrinsic moral well-being (a), expected social rewards (s) and perceived environmental quality (e). Higher waste separation efforts by other households (which the household perceives through government communication and frequency of collection of waste) impact the utility of the household via both (e) and (s): The household may perceive a better environment and may also feel the pressure of a higher social norm to increase its efforts. A household's utility function is subject to the socioeconomic, demographic characteristics of its members (including their environmental and political preferences) but also to government communication and collection frequency which can influence the moral and social benefits it perceives from recycling.

The household is constrained by finite income $(\mathrm{m})$, leisure time $\left(\mathrm{l}^{\mathrm{t}}\right)$ and space $\left(\mathrm{v}^{\mathrm{t}}\right)$. The kerbside collection of separated and mixed waste comes at a price $\left(\mathrm{GP}^{\mathrm{r}}\right.$, GP ${ }^{\mathrm{u}}$, respectively, where normally $\left.\mathrm{GP}^{\mathrm{u}}>\mathrm{GP}^{r}\right)$ as do all other goods and services $(\mathrm{x})$, whose price is $\left(\mathrm{P}_{\mathrm{x}}\right)$, normalised to unity. Recycling also diverts household time away from leisure. This relationship is subject to changes with government communications $\left(\mathrm{GC}^{\mathrm{r}}\right)$ which can educate households into more time-effective waste separation or promote convenient scheme attributes. Separated waste also consumes household space, but the frequency of collection services of recycling waste $\left(\mathrm{GF}^{\mathrm{r}}\right)$ and their promotion $\left(\mathrm{GC}^{\mathrm{r}}\right)$ can relieve this constraint. Total waste $\left(\mathrm{w}^{\mathrm{t}}\right)$ can be disposed of as either separated waste for recycling $\left(\mathrm{w}^{\mathrm{r}}\right)$ or un-separated waste $\left(\mathrm{w}^{\mathrm{u}}\right)$.

(6) $\mathrm{m}_{\mathrm{i}}=\mathrm{GP}^{\mathrm{r}} \cdot \mathrm{w}_{\mathrm{i}}^{\mathrm{r}}+\mathrm{GP}^{\mathrm{u}} \cdot\left(\mathrm{w}_{\mathrm{i}}^{\mathrm{t}}-\mathrm{w}_{\mathrm{i}}^{\mathrm{r}}\right)+\mathrm{x}_{\mathrm{i}}$

(7) $\mathrm{l}_{\mathrm{i}}^{\mathrm{c}}=\mathrm{l}_{\mathrm{i}}^{\mathrm{t}}-\mathrm{l}_{\mathrm{i}}^{\mathrm{r}}\left(\mathrm{w}_{\mathrm{i}}^{\mathrm{r}} ; \mathrm{GC}^{\mathrm{r}}\right)$ where $\delta \mathrm{l}_{\mathrm{i}}^{\mathrm{r}} / \delta \mathrm{w}_{\mathrm{i}}^{\mathrm{r}}>0$, and $\left(\delta \mathrm{l}_{\mathrm{i}}^{\mathrm{r}} / \delta \mathrm{w}_{\mathrm{i}}^{\mathrm{r}}\right) / \delta G C^{\mathrm{r}}<0$

(8) $\mathrm{v}_{\mathrm{i}}^{\mathrm{c}}=\mathrm{v}_{\mathrm{i}}^{\mathrm{t}}-\mathrm{v}_{\mathrm{i}}^{\mathrm{r}}\left(\mathrm{w}_{\mathrm{i}}^{\mathrm{r}} ; \mathrm{GF}^{\mathrm{r}}, \mathrm{GC}^{\mathrm{r}}\right)$ where $\delta \mathrm{v}_{\mathrm{i}}^{\mathrm{r}} / \delta \mathrm{w}_{\mathrm{i}}^{\mathrm{r}}>0,\left(\delta \mathrm{v}_{\mathrm{i}}^{\mathrm{r}} / \delta \mathrm{w}_{\mathrm{i}}^{\mathrm{r}}\right) / \delta G \mathrm{G}^{\mathrm{r}}<0$ and $\left(\delta \mathrm{v}_{\mathrm{i}}^{\mathrm{r}} / \delta \mathrm{w}_{\mathrm{i}}^{\mathrm{r}}\right) / \delta G C^{\mathrm{r}}<0$

Assuming all margins in the previous equations to be diminishing, solving the utility maximisation problem with respect to the key decision variables, namely the kilograms of waste to separate $\left(\mathrm{w}^{\mathrm{r}}\right)$ and the total goods and services to consume (x) (and leaving mixed waste as a residual), yields the (normal) prediction that a household will continue to recycle until the net effect of recycling on well-being divided by the money price of recycling is equal to the net well-being effect of consumption, divided by the price of consumption (plus the shadow price of (un-separated) waste).

The optimisation problem gives rise to the following Legrangian function:

$$
\begin{aligned}
& \mathrm{L}_{\mathrm{i}}=\mathrm{U}_{\mathrm{i}}\left(\mathrm{x}_{\mathrm{i}}, \mathrm{l}_{\mathrm{i}}^{\mathrm{c}}, \mathrm{v}_{\mathrm{i}}^{\mathrm{c}}, \mathrm{w}_{\mathrm{i},}^{\mathrm{r}}, \mathrm{w}^{\mathrm{rn}} ; \mathrm{d}_{\mathrm{i},}, \mathrm{GC}^{\mathrm{r}}, \mathrm{GF}^{\mathrm{r}}\right)-\lambda_{\mathrm{i}}\left(\mathrm{GP}^{\mathrm{r}} \cdot \mathrm{w}_{\mathrm{i}}^{\mathrm{r}}+\mathrm{GP}^{\mathrm{u}} \cdot \mathrm{w}_{\mathrm{i}}^{\mathrm{t}}-\mathrm{GP}^{\mathrm{u}} \cdot \mathrm{w}_{\mathrm{i}}^{\mathrm{r}}+\mathrm{x}_{\mathrm{i}}-\mathrm{m}_{\mathrm{i}}\right) \\
& -\mu_{i}\left[1_{i}^{c_{i}}+1_{i}^{r}\left(w_{i}^{r}\right)-1_{i}^{t}\right]-\kappa\left[v_{i}^{c}+v_{i}^{r}{ }_{i}\left(w_{i}^{r}\right)-v_{i}^{t}\right]
\end{aligned}
$$


Where

$\lambda$ is the shadow price of income;

$\mu$ is the shadow price of leisure time; and

$\kappa$ is the shadow price of space.

These shadow prices can be interpreted as the marginal utilities derived from loosening the constraint, or the prices that an optimising household would be willing to pay for this to be possible. In a stylised world, a household pursuing utility maximisation would choose to behave in a manner such that no more utility can be obtained by changing behavior any further, that is until:

$$
\delta \mathrm{L}_{\mathrm{i}} / \delta \lambda_{\mathrm{i}}=\delta \mathrm{L}_{\mathrm{i}} / \delta \mu_{\mathrm{i}}=\delta \mathrm{L}_{\mathrm{i}} / \delta \kappa_{\mathrm{i}} \equiv 0
$$

This utility maximisation problem can be solved with respect the kilograms of waste to separate $\left(\mathrm{w}^{\mathrm{r}}\right)$, and the total goods and services to consume (x), leaving mixed waste as the residual. Two first order conditions arise:

$$
\begin{aligned}
& \delta \mathrm{L}_{\mathrm{i}} / \delta \mathrm{w}_{\mathrm{i}}^{\mathrm{r}}=\mathrm{U}_{\mathrm{i}}^{\prime}\left(\mathrm{w}_{\mathrm{i}}^{\mathrm{r}}\right)-\lambda_{\mathrm{i}} \mathrm{GP}^{\mathrm{r}}+\lambda_{\mathrm{i}} \mathrm{GP}^{\mathrm{u}}-\mu_{\mathrm{i}}\left[\mathrm{l}_{\mathrm{i}}^{\mathrm{r}} \mathrm{i}^{\prime}\left(\mathrm{w}_{\mathrm{i}}^{\mathrm{r}}\right)\right]-\kappa\left[\mathrm{v}_{\mathrm{i}}^{\mathrm{r}}\left(\mathrm{w}_{\mathrm{i}}^{\mathrm{r}}\right)\right] \equiv 0 \\
& \delta \mathrm{L}_{\mathrm{i}} / \delta \mathrm{x}_{\mathrm{i}}=\mathrm{U}_{\mathrm{i}}\left(\mathrm{x}_{\mathrm{i}}\right)-\lambda_{\mathrm{i}} \equiv 0
\end{aligned}
$$

Making $\lambda_{\mathrm{i}}$ the subject of the formula and equating, gives rise to the condition:

$$
\left.\left\{\mathrm{U}_{\mathrm{i}}^{\prime}\left(\mathrm{w}_{\mathrm{i}}^{\mathrm{r}}\right)-\mu_{\mathrm{i}}\left[\mathrm{l}_{\mathrm{i}}^{\mathrm{r}} \mathrm{i}^{\mathrm{r}} \mathrm{w}_{\mathrm{i}}^{\mathrm{r}}\right)\right]-\kappa\left[\mathrm{v}_{\mathrm{i}}^{\mathrm{r}}\left(\mathrm{w}_{\mathrm{i}}^{\mathrm{r}}\right)\right]\right\} /\left(\mathrm{GP}^{\mathrm{r}}-\mathrm{GP}^{\mathrm{u}}\right)=\mathrm{U}_{\mathrm{i}}^{\prime}\left(\mathrm{x}_{\mathrm{i}}\right)
$$

That is, a household would recycle until the net effect of recycling on well-being divided by the (net) price of recycling is equal to the net well-being effect of consumption, divided by the price of consumption. The net well-being effect of recycling includes the utility derived from recycling (via moral and social effects) plus the benefit of less mixed waste, less the shadow price of time (and time needed to recycle the extra kilogram), the shadow price of space (and space needed to recycle the extra kilogram). The net well-being effect from consumption includes the utility benefits of extra consumption and the shadow price of waste generated by extra consumption.

On the basis of the assumption of utility maximising condition, further predictions emerge, for instance that recycling effort will be higher among households where the marginal product of recycling on time and space is lower, where the marginal utility of extra time and space is lower or where the marginal moral/social benefit of recycling is higher. Government intervention which reduces the marginal time and space required to recycle (or, for that matter, increases total time and space available to households), which increases the marginal moral/social benefits of recycling, and which reduces the relative price of recycling, will increase recycling.

Solving the system of equations above explicitly to derive a demand function for $\mathrm{w}^{\mathrm{r}}$ would require knowledge of the form of the utility function as well as of the manner in which separation of waste (and consumption of goods and services) eats into the constraints. An option is to specify a reduced form equation where $\left(\mathrm{w}^{\mathrm{r}}\right)$ is expressed as a function of the exogenous variables in the system:

(13) $\mathrm{w}^{\mathrm{r}}=\mathrm{w}^{\mathrm{r}}\left(\mathrm{l}_{\mathrm{i}}^{\mathrm{t}}, \mathrm{v}_{\mathrm{i}}^{\mathrm{t}}, \mathrm{m}_{\mathrm{i}}, \mathrm{GP}^{\mathrm{r}}, \mathrm{GP}^{\mathrm{u}}, \mathrm{GC}^{\mathrm{r}}, \mathrm{GF}^{\mathrm{r}}, \mathrm{GF}^{\mathrm{u}}, \mathrm{d}, \mathrm{w}^{\mathrm{rn}}\right)$ 
Estimation entails a number of simplifying assumptions, including that behaviour is linear in the neighbourhood of equilibrium, and that aggregated results at the locality level represent household level decisions where aggregated data is used. Moreover, a household's actual recycling could differ from the utility maximising prediction in the presence of other processes (beyond optimisation) that guide behaviour - such as habits and heuristics. The extent to which such processes cause divergence from the predictions of the very stylised model described above depends on household characteristics (and context), but also government interventions themselves - some of which may produce a more biased response. For instance, while in the model above, higher frequency of collection $\left(\mathrm{GF}^{\mathrm{r}}\right)$, is predicted to work through the mechanisms of space-relief and visibility, it may also work through the force of creating habit. This also suggests the need for caution in interpreting the results of the empirical analysis as simply the result of utility-maximising household decisions.

\section{References}

Andreoni, J. 1990. "Impure Altruism and Donations to Public Goods: A Theory of WarmGlow Giving?” Economic Journal, 100 (401): 464-477.

Brekke, K.A., Kverndokk, S. and Nyborg, K. 2003. "An economic model of moral motivation” Journal of Public Economics (87):1967-1983.

Hage, O., Söderholm, P. and Berglund, C. 2009. "Norms and economic motivation in household recycling: Empirical evidence from Sweden" Resources, Conservation and Recycling, 53 (3): 155-165.

Nyborg, K., Howarth, R.B. and Brekke, K.A. 2006. "Green consumers and public policy: On socially contingent moral motivation" Resource and Energy Economics, 28 (4): 351-366. 